\title{
Review
}

\section{In search of the Black fantastic: Politics and popular culture in the post-civil rights era}

\author{
Richard Iton \\ Oxford University Press, New York, 2008, 432pp., \$21.95/£14.99 \\ ISBN-13: 978-019973606 \\ Contemporary Political Theory (2013) 12, e1-e4. doi:10.1057/cpt.2012.16
}

Harry Belafonte, the Congressional Black Caucus, jazz ambassadors, Rastafarianism, Spike Lee, Alice Walker, 'queer space', the Black Star Line. Autobiography, hip-hop, political speeches, Black Arts poetry, stand-up comedy, rhythm and blues. Incomplete though they are, these lists indicate the dizzying range of artistic and political figures, movements, genres and styles that make Richard Iton's In Search of the Black Fantastic a landmark work of scholarship. For political theorists, the book poses a powerful challenge: it demands a confrontation with cramped visions of politics and political thinking that undermine our capacity to assess our political circumstances. In this regard, Iton's project is recognizable as a critique of the limitations of the canon. Yet In Search of the Black Fantastic aims at something larger: 'to identify how we might situate popular culture in general, and black popular culture in particular, in relation to both the formally and informally political' and 'to consider the implications of reading culture as politics in the context of the post-civil rights era' (p. 4). Drawing explicitly from expressive practices that deviate from and contest what is conventionally thinkable and sayable in modern political life, Iton's interpretation of 'black politics' requires that readers rethink the bounds of the political itself.

Although Iton is not the first scholar to grapple with the intricate connections between culture and politics, In Search of the Black Fantastic stands apart in both range and specificity. On the one hand, Iton goes beyond more selective studies of the relationship between politics and literature or film or music to engage forms of popular culture that regularly escape political theoretical notice. On the other, he resists both political scientific efforts to narrow 'politics' to the formal institutions of the state and cultural studies arguments that treat 'politics' as a catchall term, encompassing virtually anything but formal politics. This is treacherous terrain, because black expression, insofar as it is recognized as distinctively or particularly 'black', is too easily diminished or

(C) 2013 Macmillan Publishers Ltd. 1470-8914 Contemporary Political Theory Vol. 12, 4, e1-e4 www.palgrave-journals.com/cpt/ 
even ridiculed by whites (see Dawson, 2011), and it has historically been devalued politically insofar as it has been celebrated as culture.

The force of Iton's argument resides not only in his sharp readings of cultural texts and political moments, but also in the mode of presentation. Rather than simply explaining how apparently unrelated political and cultural phenomena are connected, he relates them dynamically. In this regard, In Search of the Black Fantastic testifies to the political work of resonance through its juxtapositions of cultural and political events, close readings of song lyrics or poetry and official speech; without explicitly citing the concept, Iton enlarges recent explorations of resonance by William Connolly, Cristina Beltrán and Romand Coles. Iton's deft blend of conceptual analysis and performance serves him especially well, furthermore, when he turns to debates about the uses of diaspora. In Search of the Black Fantastic both offers a theoretical account of diaspora as an alternative site of identification and critique of the nation-state, and simultaneously evinces a diasporic sensibility in its ease of movement from Jamaican music to politics in the United States and back again.

In Search of the Black Fantastic brims with incisive interventions into numerous scholarly conversations about race and democracy. For instance, Iton's reading of Ralph Ellison's 'almost primal attachment to the American project and his resistance to the joining of the creative arts and politics' (p. 75) may not be entirely new (see Watts, 1994). Yet Iton injects a timely note of caution into recent discussions of Ellison's power as a democratic thinker (see Allen, 2004). The point is not to discredit the accomplishment of Invisible Man or the force of Ellison's writing on the blues or the acuity of his response to Hannah Arendt's misreading of Little Rock, but to recall alternative paths laid down by figures like Paul Robeson, who struggled across his career to link his artistic and political projects. Similarly, Iton deepens recent debates about the political meaning of everyday acts of resistance occasioned by scholars such as Robin Kelley and James Scott (p. 101ff). He offers an appreciative but critical reading of Kelley and Adolph Reed that undercuts tendencies among left academics either to interpret every act of transgression as politically salient or to dismiss too completely the creative agency of the oppressed outside normal political channels.

Iton's work also contributes a new degree of temporal specificity to the recent stream of books that consider racial politics in the post-civil rights era. In Search of the Black Fantastic usefully differentiates between the politics of the period that immediately followed the modern civil rights movement and what he calls the 'post-post-civil rights' period. In the book's first three chapters, Iton traces how black political actors responded to the imperatives of the Cold War and triumphs of the civil rights movement by attempting to narrow the terms of what and who counted in the definition of 'proper black politics'. He builds on and supplements Cathy Cohen's work and he insists that 
any inquiry into the black fantastic must look and listen for subjectivities that have been deemed beyond 'the boundaries of blackness' (Cohen, 1999). In subsequent chapters, Iton complicates recent arguments about the development and eclipse of black counter-publics by discerning the emergence of a 'superpublic' in the mid-1980s and exploring the merger of a heightened visibility of black culture, hip-hop particularly, with a retreat from progressive politics. He also raises larger questions about the politics of vision, exploring how the proliferation of visual images of black Americans, rather than undoing the harms of historic invisibility, coincided with and fed that retreat.

In Search of the Black Fantastic is mostly demanding in the right ways. The elusiveness of some of its claims mirrors the hazards of trying to follow the arc of political developments that do not proceed in straightforward, linear fashion. Still, there are places where the density of the text disserves the argument. Some of the terminology - for example, 'antidactylic metric template' (p. 81) or the distinction between the 'duppy state' and the 'prophylactic state' (p. 135) - is sufficiently obscure to send the reader off the track. Relatedly, the book sometimes devotes extensive attention to strands of argument that might be more productively pursued elsewhere. Iton's discussion of Foucault's limitations as a theorist of race and colonialism, for example, is interesting in its own right. But it makes a frustrating introduction to an otherwise brilliant reading of black elected officials' unwillingness to oppose welfare reform or Bill Clinton's reelection, while black popular culture registered and struggled over the very entanglements of race, gender and class that were elided in formal political discourse.

What is 'the black fantastic'? Although Iton does not provide a definitive answer, his own argument offers a generative example. Looking and listening for the black fantastic demands that readers attune themselves to the lingering grip of coloniality in a polity that has rarely imagined itself in colonial or postcolonial terms (heroic stories of Lexington and Concord, notwithstanding) and to the ways in which black artists, activists and intellectuals have transgressed the bounds of what can be said and thought in political life. Iton's message, I think, is that democracy is more imperiled than political theorists generally admit. But the story does not end there. By offering fugitive glimpses of the fantastic possibilities of black culture and showing how they have made and can yet make an imprint on formal politics, Iton reminds readers that opportunities for wresting some form of freedom from oppressive political circumstances admit no bounds.

\section{References}

Allen, D.S. (2004) Talking to Strangers: Anxieties of Citizenship since Brown v. Board of Education. Chicago, IL: University of Chicago Press. 
Cohen, C.J. (1999) The Boundaries of Blackness: AIDS and the Breakdown of Black Politics. Chicago, IL: University of Chicago Press.

Dawson, M.C. (2011) Not in Our Lifetimes: The Future of Black Politics. Chicago, IL: University of Chicago Press.

Watts, J.G. (1994) Heroism and the Black Intellectual: Ralph Ellison, Politics, and Afro-American Intellectual Life. Chapel Hill, NC: University of North Carolina Press.

Lawrie Balfour University of Virginia, Charlottesville, VA 22904, USA 